\title{
Cultural Explanations of Electoral Reform: A Policy Cycle Model
}

\section{Citation}

Norris, Pippa. 2010. Cultural Explanations of Electoral Reform: A Policy Cycle Model. Faculty Research Working Paper Series, RWP10-022, John F. Kennedy School of Government, Harvard University.

\section{Published Version}

http://web.hks.harvard.edu/publications/workingpapers/citation.aspx?Publd=7338

\section{Permanent link}

http://nrs.harvard.edu/urn-3:HUL.InstRepos:4449095

\section{Terms of Use}

This article was downloaded from Harvard University's DASH repository, and is made available under the terms and conditions applicable to Other Posted Material, as set forth at http:// nrs.harvard.edu/urn-3:HUL.InstRepos:dash.current.terms-of-use\#LAA

\section{Share Your Story}

The Harvard community has made this article openly available.

Please share how this access benefits you. Submit a story.

\section{Accessibility}




\section{Cultural Explanations of Electoral Reform: A Policy Cycle Model Faculty Research Working Paper Series}

\section{Pippa Norris}

Harvard Kennedy School

\section{J une 2010 RWP10-022}

The views expressed in the HKS Faculty Research Working Paper Series are those of the author(s) and do not necessarily reflect those of the John F. Kennedy School of Government or of Harvard University. Faculty Research Working Papers have not undergone formal review and approval. Such papers are included in this series to elicit feedback and to encourage debate on important public policy challenges. Copyright belongs to the author(s). Papers may be downloaded for personal use only. 
Revised 3 January 2010

\title{
Cultural explanations of electoral reform:
}

\author{
A policy cycle model
}

Pippa Norris 


\section{Abstract:}

The standard explanation of electoral reform is offered by rational choice accounts. These regard the choice of rules as an elite-level issue, dominated by partisan interests bargaining within the legislature, where citizens are usually marginalized and powerless. Such accounts may help to explain what specific reforms are enacted but they lack the capacity to account satisfactorily for the logically prior questions: when and why are any successful reforms raised on the policy agenda?

Part I presents a general policy cycle model identifying multiple actors in the process of electoral change. Working within this framework, the study seeks to test the proposition that political culture -- notably citizen dissatisfaction with regime legitimacy -- heightens the salience of institutional reform on the policy agenda. Part II summarizes the research design testing this proposition. Perceptions of regime legitimacy are measured at three levels: citizens' aspirations for democracy, satisfaction with the performance of democracy, and confidence in regime institutions. Evidence draws upon the $2^{\text {nd }}$ and $3^{\text {rd }}$ waves of the World Values Survey (WVS), in the early to mid1990s, covering almost fifty countries around the globe. Patterns of institutional reform are measured by major changes to the electoral systems used for the lower house of parliament during the following decade. The study uses binary logistic regression to test whether macro-level perceptions of regime legitimacy in the early to mid1990s influenced whether electoral reforms were passed during the subsequent decade, controlling for levels of democracy and development. Part III presents the results. The evidence demonstrates that democratic aspirations (support for democracy as an ideal) are a strong, significant, and robust predictor of the occurrence of subsequent electoral reforms. The conclusion in Part IV considers the implications of these findings, both for theories concerning regime legitimacy, as well as for revising standard accounts of processes of institutional change.

Word Length: 7,935+ 301 abstract

Keywords: electoral reform, political culture, public opinion

Bio:

Pippa Norris is the McGuire Lecturer in Comparative Politics at Harvard University's John F. Kennedy School of Government. Pippa Norris@Harvard.edu

\section{Contact address:}

John F. Kennedy School of Government, 79 JFK St, Harvard University, Cambridge MA 02138 
The standard explanation of modifications to electoral rules is provided by rational choice theories. This perspective depicts policy change as an elite-level game among rival partisan interests, where the outcome depends upon the calculation of gains for office-holders (Tsebelis 1990, Boix 1999, Benoit 2004, 2007). According to this theory, the public may demand institutional reforms, as part of the agenda-setting process. But it would be naïve to assume that political elites will necessarily respond to these pressures, if the outcome runs counter to partisan interests. This paper challenges this approach and reasserts the central role of the public in catalyzing electoral change. To provide an alternative viewpoint, this paper develops a general policy cycle model identifying multiple actors and sequential steps in the complex process of maintaining and modifying electoral rules. Working within this model, the study predicts that lack of legitimacy is a major factor catalyzing political pressures for electoral change. Several descriptive case studies suggest that this is a plausible hypothesis; hence, for example, during the early 1990s, Italian electoral reform was widely interpreted as a reaction to the Tangentopoli scandal (Donovan 1995), while public anger about government corruption was also seen as one of the main triggers for Japanese reforms (Shiratori 1995). After comparing the series of major electoral reforms occurring in established democracies since 1950, Katz concludes that 'public outrage' featured as a common factor in all cases (Katz 2005). For Reynolds, Reilly, and Ellis (2006, 20), as well, electoral system changes occur either during the initial process of regime transition, or else when there is a 'crisis of governance' involving 'hugh public mistrust and dissatisfaction with the political system.' Gallagher (2005) argued that widespread public disaffection has the potential, like 'woodworm', to undermine the foundations of the electoral system, until it suddenly caves in. Therefore although often assumed in descriptive accounts, cultural explanations of institutional reform have not been clearly and rigorously demonstrated in the research literature using systematic cross-national evidence, especially across a wide variety of contexts (Dalton 2004, Booth and Seligson 2009).

To advance the debate, Part I develops a policy cycle model to identify the multiple actors and sequential stages involved in the maintenance and modification of electoral rules. We then develop several testable propositions for the role of public opinion in this process. Part // outlines the sources of evidence and the research design. Testing the cyclical model fully requires information about public opinion at $\mathrm{t}^{1}$, electoral reforms at $\mathrm{t}^{2}$, and then subsequent changes in public opinion at $\mathrm{t}^{3}$. Here the first two steps in the process are tested empirically. To establish public attitudes in $t^{1}$, prior to electoral reforms being introduced the study draws upon the $2^{\text {nd }}$ and $3^{\text {rd }}$ waves of the World Values Survey (WVS) 
conducted in the early-to-mid 1990s, covering 50 countries around the world. ${ }^{1}$ Perceptions of the political legitimacy are conceptualized to operate at three levels, ranging from the more diffuse to the more specific: democratic aspirations, measured by support for democratic ideals which have been found to be distinct (Norris 2012); democratic performance, measured by public satisfaction with the performance of democracy in each country; and institutional confidence, especially trust in parties and parliaments. The dependent variable monitors major changes to electoral systems during the subsequent decade $\left(\mathrm{t}^{2}\right)$, from 1993 to 2004, in all countries worldwide. Changes are classified from successive editions of the International IDEA Handbook of Electoral System Design (Reynolds and Reilly 1997, Reynolds, Reilly and Ellis 2006). This comparison identifies almost four dozen cases of major reforms during this period, mostly in developing countries and in transitional regimes and electoral democracies. Among these, almost half (21 cases) are in countries contained in the WVS survey. Since the theory predicts the effects of public opinion on the policy agenda, regression models are used with the survey data analyzed at societal-level.

Part III presents the results monitoring the impact of public opinion on institutional change, controlling for macro-level factors, including levels of democracy and development. Most importantly, among all cultural factors, the results demonstrate that democratic aspirations prove the strongest and most significant predictors of the subsequent adoption of electoral reforms. Indeed democracy aspirations are stronger predictors of reform than levels of economic or human development, the historical record of democracy in each country, as well as cultural indictors such as satisfaction with democratic performance and institutional confidence. The conclusion considers the implications, both for theories concerning electoral reform, as well as for understanding the role of public opinion in broader process of institutional change.

\section{Theoretical framework and literature review}

\section{Rational choice institutionalism and partisan interests}

What drives change to electoral rules? The standard approach predominating in the literature is based upon rational choice institutionalism. These accounts emphasize the paramount importance of the calculation of partisan interests in a two-stage game, where parties have preferences for alternative institutions based on expectations about the payoffs these rules will have for them in future (Cox 1997, Boix 1999, Colomer 2004, Benoit 2004, 2007, Bowler et al 2006). The key decision-makers are seen as 
actors within the legislature and the executive who seek to maintain or revise constitutional, legal and regulatory frameworks when calculating the optimal rewards in elected office anticipated from any rule changes. In these accounts, the concept of partisan interest is often framed relatively narrowly, in terms of policy outcomes, office-seeking, and personal gain for key individuals. Partisan interests can also be conceptualized more broadly, however, to include general value or ideological preferences, for example when parties seek reforms based on the principles of fairness, governability or social representation, although doing so carries the danger of generating tautological explanations which lose their analytical power.

Rational choice approaches to electoral institutions have been developed in a series of recent studies; for example, in a widely-cited article, Carles Boix (1999) argued that the choice of electoral systems derives from the decisions ruling parties make to maximize their representation. As long as the electoral arena does not change and the current rules benefit the ruling parties, the electoral system is not altered. As the electoral arena changes (due to the entry of new voters or a change in voters' preferences), the ruling parties modify the electoral system, depending on the emergence of new parties and the coordinating capacities of the old parties. Similarly, Kenneth Benoit $(2004,2007)$ posits that electoral laws change when two conditions are fulfilled: (i) when a party coalition forms with the power to alter electoral rules; and (ii) where each party in the coalition expects to benefit by gaining more seats under alternative electoral institutions. Echoing these views, Josep Colomer (2004) argues that existing parties in assemblies and governments tend to prefer the electoral formulas that reinforce their power, with party fragmentation in many countries gradually encouraging the adoption of more inclusive formulas. The rational choice approach is attractive because of its theoretical parsimony and elegance. It provides a simple way to compare diverse countries and types of reforms, generating some clear propositions about which types of reforms will be adopted. The propositions are testable against the empirical evidence if data is available on (i) the partisan composition of national legislatures and (ii) the enactment of legal statutes governing electoral institutions. The approach provides few insights, however, which could be used to generate plausible explanations concerning underlying processes and contexts which constrain or facilitate elite-level actions, including the prior step of agenda-setting in the public sphere. 


\section{Challenges arising from historical institutionalism}

The idea that partisan interests and elite actors alone drive the process of electoral reform has been subject to extensive critique; hence Katz (2005) presents a series of reasons why rational choice theory fails to predict the outcome, including cases where changes are imposed on ruling parties; members of the winning coalition are divided; politicians miscalculate the unforeseen consequences of new rules; parties value long-term change over short-term electoral advantage; and parties trade electoral advantage for other goals.

Moreover the wealth of case-study descriptions in the literature emphasize the complexity of the process of electoral reform, including the convergence of multiple actors and forces, and the contingent impact of idiosyncratic events (Norris 1995). In describing reform in Israel, for example, Rahat (2004) rejects rational choice theories as over-simplifying the complex reality of the multi-stage bargaining process and the motivations of the key actors. In the UK, as well, the rational choice approach fits uneasily with the actions of the Blair Labour government, which implemented a series of reforms which weakened the traditional SMD plurality system at every level except Westminster, and thus two-party predominance, despite enjoying a massive parliamentary landslide in 1997 and the largest majority in its history (Norris 2001). The UK case remains a puzzle, according to the rational choice perspective, unless the notion of 'self-interest' is stretched so far as to become almost meaningless.

Rational choice accounts also assume that legislative parties can act relatively autonomously when manipulating or maintaining electoral rules to further their self-interest, without constraint. Yet case studies also emphasize that legislative and executive elites are typically constrained by other actors and institutions, such as constitutional courts or judicial review, and by the broader political culture. The paramount role of constitutional referendums was evident in the New Zealand and Italian cases. Detailed 'before' and 'after' case-studies have documented the dynamics of public opinion surrounding electoral reforms occurring within particular countries, such as New Zealand (Banducci et al 1999, Banducci and Karp 1999) and the UK (Weir 2005, Curtice 2004). Yet it remains difficult to generalize more widely from these particular contexts to transitional regimes and developing countries where the vast majority of electoral rule changes have occurred in recent years. 
The policy cycle model of institutional stability and change

The rational choice and the historic case-study approaches are often regarded as offering competing perspectives but of course these are not necessarily either/or explanations; if understood more comprehensively as a cyclical sequential process, where public disaffection and lack of political legitimacy could plausibly serve as the long-term context generating political pressures for change, getting the issue of reform onto the policy agenda, while elite-level bargaining among parties could determine the formulation of policy proposals and the negotiated outcome of the decision-making process. Although electoral rule changes represent one specific type of public policy issue --involving the redistribution of power -- this does not imply that scholars need to abandon standard approaches to understanding the policymaking process.

The roots of the policy cycle approach can be traced back historically to David Easton's (1965) notion of a political system, as well as drawing upon notions of public policymaking as a multistage process (Dye 1995). The cyclical model proposed in this study identifies multiple actors as players in a sequential policymaking process, illustrated in Figure 1, with four distinct steps: (i) the agenda-setting stage in the public sphere, engaging the public, political parties, the media and NGOs, which heightens the salience of institutional reform as a key problem to be addressed on the policy agenda; (ii) the policy-making stage in the state, where policy options are formulated, coalitions are built, and regulatory policies are adopted to address these perceived problems, directly engaging decisions by political parties in the legislature and the executive, as well as, indirectly, the influence of public referendums and international diffusion; (iii) the implementation stage, where the revised regulatory framework is put into practice in subsequent elections, involving election management bodies and the courts; and finally, (iv) the feedback evaluation loop, when learning about the consequences of the new regulatory framework shapes either satisfaction with the status quo or further demands for subsequent revisions. All this activity is understood to occur within a broader environment in each country, including the role of path-dependent historical traditions, the social structure and culture, and the economic structure. This cycle regards the policymaking process as a series of activities - involving problem identification, agenda-setting, formulation, legitimation, implementation, evaluation and feedback.

[Figure 1 about here] 
The general model is sufficiently flexible to apply to any major dimension of public policymaking, rather than generating sui generis explanations of electoral reform, while recognizing significant factors common to diverse reform efforts in a wide variety of contexts. It also has the advantage of identifying a more comprehensive range of actors and a broader series of stages than rational choice accounts, which focus only upon the role of partisan interests within the legislature. The general model remains agnostic, however, about the precise impact of each type of actor in the policy process, for example the relative weight of the public, NGOs and the media in agenda-setting, and whether referenda or international agencies influence the legislature. The proposed notion of a feedback loop is particularly important to understand countries which have modified their electoral rules and then revised them again within a few years, such as France, Italy and Israel, as the consequences of the new system became apparent.

Within this general cyclical model, this study focuses on examining evidence concerning the agenda-setting stage, and, in particular, the role of public evaluations of the legitimacy of regime institutions. In understanding this process, we can draw upon a useful distinction, suggested by Shugart and Wattenberg (2001), between inherent factors, focused on pre-existing long-term conditions, and contingent factors, or tipping points, which trigger a specific event. In democratic states (where public concerns can be freely expressed without fear of reprisal or repression), the policy cycle model postulates that aspirations for democratic change, citizen disaffection with specific elections, and lack of public confidence in core regime institutions, represent inherent conditions heightening the issue of electoral reform on the policy agenda, and thus encouraging the formulation and enactment of revised regulations by the legislature. In particular, this study builds upon cultural theories which have long suggested that political legitimacy is the foundation of stable democratic institutions (Eckstein 1961). The concept of 'legitimacy' represents acceptance of the underlying 'rules of the game', so that all actors, even electoral losers, willingly consent to accept the regime, without the sanction of force. Legitimacy, in Seymour Martin Lipset words, "involves the capacity of a political system to engender and maintain the belief that existing political institutions are the most appropriate and proper ones for the society." (Lipset 1983, 64) Lack of legitimacy should mobilize pressures for reform, encouraging debate about policy options among the media, parties, and NGOs. In transitional regimes, as well, where the public is free to express their concerns, aspirations for more democratic reforms should mobilize democratic movements. By contrast, where regime institutions are widely regarded as legitimate, this should stabilize and 'freeze' opportunities for reform. In this regard, in democracies, perceptions of 
political legitimacy of regime institutions are an important check on the actions of legislative elites. Whether elected officials respond to public opinion depends upon many contingent conditions. Citizen disaffection was document during recent decades in many established democracies, after all, without necessarily resulting in major changes to electoral systems (Norris 1999, Dalton 2004). A growing comparative literature has started to the role of institutions in shaping the political attitudes (Anderson 1997, 2001, Anderson et al 2005, Norris 2002, Birch 2008). What is less apparent, however, is the reverse relationship, in particular whether public attitudes are one of the factors driving concern about electoral reform on the policy agenda.

\section{Research design, data and methods}

The most effective comparative research design ideally requires evidence about public opinion at $\mathrm{t}^{1}$ across a broad range of independent nation states, as well as subsequent patterns of electoral reform at $\mathrm{t}^{2}$, and any subsequent changes in public attitudes at $\mathrm{t}^{3}$. Individual-level evidence about attitudes in many different societies is derived in this study from two surveys. The broadest comparative analysis is available from the World Values Survey (WVS), a global investigation of socio-cultural and political change carried out from 1981 to 2007. This project has carried out representative national surveys of the basic values and beliefs of the publics in more than 90 independent countries, containing over 88 of the world's population and covering all six inhabited continents. For this analysis, we select survey data conducted prior to the enactment of the electoral reforms under comparison. Data draws upon the second wave of surveys, completed in 43 countries in 1990-1991, and the third wave, carried out in 55 nations in 1995-1996. ${ }^{2}$ The WVS includes some of the most affluent market economies in the world, such as the U.S., Japan and Switzerland, with per capita annual incomes over $\$ 40,000$; together with middle-level countries including Mexico, Slovakia, and Turkey, as well as poorer agrarian societies, such as Ethiopia, Mali and Burkina Faso, with per capita annual incomes of $\$ 200$ or less.

There are also significant variations in levels of human development in the countries under comparison in the WVS, as monitored by the UNDP Human development Index combining per capita income with levels of education, literacy and longevity. Some smaller nations also have populations below one million, such as Malta, Luxembourg and Iceland, while at the other extreme both India and China have populations of well over one billion people. The survey contains older democracies such as Australia, India and the Netherlands, newer democracies including El Salvador, Estonia and Taiwan, and 
autocracies such as China, Zimbabwe, Pakistan, and Egypt. The transition process also varies markedly: some nations have experienced a rapid consolidation of democracy during the 1990s; today the Czech Republic, Latvia, and Argentina currently rank as high on political rights and civil liberties as Belgium, the United States, and the Netherlands, which have a long tradition of democracy. ${ }^{3}$ This data allows us to compare public attitudes which could plausibly heighten or dampen the prospects for reform of electoral institutions on the policy agenda. The selected indicators includes aspirations for democracy, satisfaction with the performance of democracy, and also patterns of institutional confidence, especially concerning political parties, governments, and parliaments. All of these values and attitudes are key indices of system support which factor analysis suggests fall into distinct dimensions (Norris 2012). The technical appendix gives details about the particular questions used for the analysis. For the nationallevel institutional context, many factors could shape evaluations of political legitimacy. For each country, successive models controlled for levels of economic development (logged per capita GDP in purchasing Power Parity) and for the longevity of democracy (measured by the mean civil liberties and political rights annual scores estimated from 1972-1995 by Freedom H), to see if levels of development and experience of a succession of democratic contests also shaped public attitudes.

\section{Classifying and measuring electoral reforms}

To operationalize the dependent variable, we need to unpack what counts as an 'electoral reform' and establish which countries have changed their electoral rules in the period under review. Ever since seminal work by Maurice Duverger (1954) and by Douglas Rae (1971), a rich literature has developed typologies of electoral systems and analyzed their consequences. The most common approach has compared established democracies in the post-war period to identify the mechanical impact of changes to electoral institutions upon seat and vote distributions, and thus patterns of party competition, as well as the representation of women and ethnic minorities, issues of governability and political stability, types of constituency service and legislative behaviour, patterns of ethnic conflict, and levels of voting turnout (Norris 2004). When comparing Western democracies, the logic of treating electoral rules as stable equilibrium institutions made much sense from the post-war era until the early1990s; with a few exceptions, in most European states the basic electoral system usually persisted in recognizable form for decades, or even centuries. For example, Bartolini and Mair (199) noted only fourteen unbroken transitions in Europe between 1885 and 1985, defined as a major shift in electoral 
rules between two democratic elections, excluding disruptions caused by wars, dictatorships, establishment of a new state, or the reappearance of an old one. Katz (2005) identified only fourteen cases of wholesale electoral system reform in established democracies since the 1950s, and five of these occurred in one country (France). In Western countries the electoral rules of the game appeared settled and predictable, although more minor electoral regulations were modified at more regular intervals, typified by adjustment to voting thresholds, electoral formulas, and suffrage qualifications (Carstairs 1980; Noiret 1990). Nevertheless these estimates remain highly conservative. It is important to compare a broader range of countries and types of regimes to generalize about this phenomenon more widely; any analysis which focuses only upon established democracies, and which is further restricted to the limited number of 'major' cases of electoral system reform, provides a deeply skewed and atypical set of cases, under-estimating the degree of volatility to electoral rules common in countries which have more recently experienced the transition from autocracy and the consolidation of democratic elections.

During the 1990s, a body of literature evolved to understand the dynamics of 'electoral engineering' (Shugart and Wattenberg 2001; Colomer 2004; Norris 2004, Gallagher and Mitchell 2005). This shift was driven in part by the major changes to electoral systems in some established democracies since the early-1990s. The notions of what counts as 'electoral reform' was also broadened by the professionalization of electoral management bodies, the rapidly growing legal and administrative frameworks regulating political finance and media campaign coverage, and the use of legal gender quotas and reserved seats in the candidate nomination process. The international community's engagement in electoral processes renewed debate about standards of electoral integrity.

This study is limited to comparing the impact of major changes to the type of electoral systems used worldwide for the lower house of the national parliament at two points of time, in 1993 and in 2004. As such, this study provides a conservative estimate of the total number and frequency of modifications to electoral rules, and further research is required to compare the role of public opinion in many other types of rule changes. Following Lijphart (1994), an electoral system is understood to represents a set of consistent electoral rules (whether constitutional, legal or administrative) under which one or more successive elections for the lower house of the national parliament are conducted within an independent nation state. The most basic components of electoral systems concern the electoral formula, determining how votes are counted to allocate seats. These were classified for the 
purpose of the study into three major electoral families, each including a number of sub-categories of electoral systems used for elections to the lower house of the national parliament in independent nation-states worldwide. The typology is drawn from previous work (Norris 2004) and it distinguishes majoritarian systems (including First-Past-the-Post, Second Ballot, the Block vote, Single NonTransferable Vote, and Alternative Voting systems); combined systems (otherwise called 'mixed', incorporating both majoritarian and proportional formula, whether Combined Independent (parallel) or Combined Dependent (such as MMP)); and proportional systems (including Party Lists as well as the Single Transferable Vote systems).

Based on this classification, electoral reforms are defined relatively narrowly as major changes to the electoral system in the period from 1993 to 2004. Data is drawn from the appendices contained in successive editions of the International IDEA Handbook of Electoral System Design (Reynolds and Reilly 1997, Reynolds, Reilly and Elis 2006). There are also a few cases lacking an elected legislative body in the constitution (such as in Saudi Arabia), as well as a few more complicated cases to classify, where the constitution or legislature is 'temporarily' suspended for an indefinite period, for example due to a military coup (e.g. Burma, Thailand), or due to a period of internal conflict in failed states (e.g. Eritrea). In addition, in a few cases absolute autocracies have introduced elections for the lower house for the first time, replacing previously-appointed or advisory bodies, and these are also counted as cases of electoral system change.

\section{[Tables 1 about here]}

Based on this classification, estimates of the number and distribution of changes to electoral systems in 190 independent nation-states around the world from 1993 to 2004 are summarized in Table 1. Details of the coding are also listed in the appendix Table 1A. It is apparent that almost three quarters (145 or 76\%) of all countries, listed in bold on the diagonal in Table 1, have kept the same electoral system throughout these years. Nevertheless this still means that one quarter (46 or $24 \%$ ) of all countries changed their electoral system during this period, not surprisingly providing a far higher estimate of levels of institutional volatility than is traditionally assumed by comparisons based upon established democracies. Moreover among all types of electoral systems, it is the countries which used First-Past-the-Post (single member plurality) systems which have most commonly revised their laws, moving either to other types of majoritarian systems, such as AV (Fiji and Papua New Guinea), and to 
SNTV (such as Afghanistan), or alternatively shifting further across the spectrum to a combined dependent system (Lesotho), or even straight to List PR (Rwanda). As Colomer (2004) observed, there are few recent cases of states moving in the other direction, from PR electoral systems towards majoritarian arrangements. In nearly all cases the shift has been in the direction of power-sharing, generating lower electoral thresholds for representation.

\section{Does public opinion affect electoral reform?}

The aim of this study is not to explain what types of electoral systems were adopted but rather to address the prior question: why did these changes happen at all? And, in particular, does public disaffection play an important role in processes of institutional change, or is this mainly an elite-level process of bargaining and accommodation occurring within the executive and legislature, as rational choice theorists imply? Using $2^{\text {nd }}$ and $3^{\text {rd }}$ waves of the WVS, institutional confidence was measured in the early-to-mid 1990s by items gauging confidence in parliament, political parties, government and the civil service. Responses to these four items were summed to generate a reliable and well-distributed 100-point standardized scale (Cronbach's Alpha=.824). Technical details about all the items are given in the appendix. In addition, at the more diffuse level, similar 100-point standardized scales measuring approval of the performance of democracy in each country and also democracy aspirations, measured by approval of democracy as an ideal, were also compared from the same waves of the WVS survey in the early-to-mid 1990s. Since the effects of public opinion are predicted to occur on the policy agenda in each nation, the analysis was conducted with public opinion aggregated at this level. The dependent variable under investigation was a binary variable coded for whether countries changed their electoral system from 1993-2004, based on the classification discussed earlier.

[Table 2 about here]

A series of binary logistic regression models were run, as presented in Table 2, for the 50 countries under comparison. Model A included the historical record of democracy, while models B included economic development and Model C human development. All the analysis was checked through tolerance statistics to avoid problems of multicollinearity, for example in the interaction between economic and democratic development. The results indicate that democratic aspirations in society (support for democracy as an ideal measured from the early-to-mid 1990s) was the most powerful and significant cultural predictor of subsequent electoral changes (occurring in the period from 
1993-2004). Countries where the public expressed strong hopes for democratic values and principles proved most likely to reform their electoral systems. By contrast, levels of institutional confidence and evaluations of the actual performance of democratic governance were not significant in any of these models. Moreover the impact of democratic aspirations was consistently significant and robust, irrespective of the controls which were introduced for levels of economic and human development. In addition, the cumulative historical record of democracy in a country, from 1972 to 1992, (as gauged by Freedom House's assessment of civil liberties and political rights), proved a significant but weaker predictor of electoral reform.

[Figure 2 about here]

To examine the distribution of countries further, Figure 2 shows the scatter-gram illustrating the underlying relationship between the historical experience of democracy (on the horizontal axis) and the aspirations for democratic ideals (on the vertical). It is apparent that there is a broad scatter across the regression line among the group of countries which have not experienced electoral reform, with some countries in the top right-hand corner, such as Norway, with strong democratic ideals and experience of democracy. By contrast, others are loosely distributed across the graph. Among the group of countries which have introduced electoral reforms, however, there is a more consistent relationship, and stronger tensions between democratic aspirations and experience of democratic practices. It is this group of countries where public aspirations for democratic ideals are most closely related to institutional reform outcomes. Unfortunately the number of cases is too limited to explore further whether there are any regional patterns, such as any distinct clusters of countries.

\section{Conclusions and discussion}

The standard rational choice account of the process of electoral reform suggests that parties seek to maximize their seat gains arising from alternatives electoral rules. This approach generates a series of empirically-testable predictions; all other things being equal, for instance, smaller parties are predicted to prefer power-sharing rules, while larger parties are expected to advocate powerconcentrating rules. Strategic bargaining among decision-makers in the legislative arena is assumed to determine the outcome. Although an elegant and parsimonious theory, the rational choice approach fits uneasily with the wealth of counter-evidence provided by historical descriptions of specific institutional changes occurring within particular countries. Detailed accounts of electoral reform, 
notably the well-known cases of Italy, New Zealand, Israel, and the UK, as well as many accounts of the process of regime change elsewhere, usually emphasize the incremental, contingent, sui generis, pathdependent, and multifaceted nature of the policymaking process, as well as the often unexpected nature of the outcome, defeating attempts to foresee partisan benefits. Moreover the rational choice account focuses upon legislative elites without considering the broader context set by public opinion, both how perceptions of political legitimacy constrain rule-changes as well as occasionally pressuring legislators to address reform issues.

Case studies suggest that, at least in democratic states, reservoirs of political legitimacy dampen the prospects of reform, where public opinion acts as ballast which anchors institutions within cultural constraints. Conversely, more critical evaluations about the fairness and honesty of specific elections, and weaker feelings of regime legitimacy, are expected to strengthen prospects for change, driving reforms from below. The survey evidence derived from multiple societies presented in this study shows that public opinion should not be discounted, confirming the observations that many case studies of specific reforms have usually emphasized. The policy cycle model provides a more satisfactory and comprehensive framework to understand the multiple actors engaged in any institutional changes - and the steps in the process from the process of agenda-setting through the public policy agenda to the legislative outcome, the administrative and legal process of implementation, and the final feedback loop leading back to public opinion. The framework facilitates further research identifying the role of multiple actors- such as the Election Management Bodies, the media and NGO agendas, and referendums, as well as what occurs within the legislature and executive. Indeed to assume that the latter act in isolation from broader political processes and from the societal context, as rational choice accounts suggest, seems dangerously naïve. The main finding from the comparative empirical evidence considered here is that mass aspirations for democracy are indeed one of the factors which help to catalyze the agenda for successful reform movements and legislative initiatives. Moreover the fact that public aspirations are followed by subsequent institutional changes, even in many non-democratic regimes, suggests that 'reform from below' is an important strategy which can succeed, even against elite interests. That the effects of this process are evident is all the more remarkable given the long chain of causality and the multiple actors and many complex stages which are required in the process of institutional reform. The results should hearten democratic forces and mass reform movements everywhere which are seeking to strengthen democratic regimes and electoral institutions. 
Figure 1: The policy-cycle model of the origins, maintenance and reform of electoral institutions

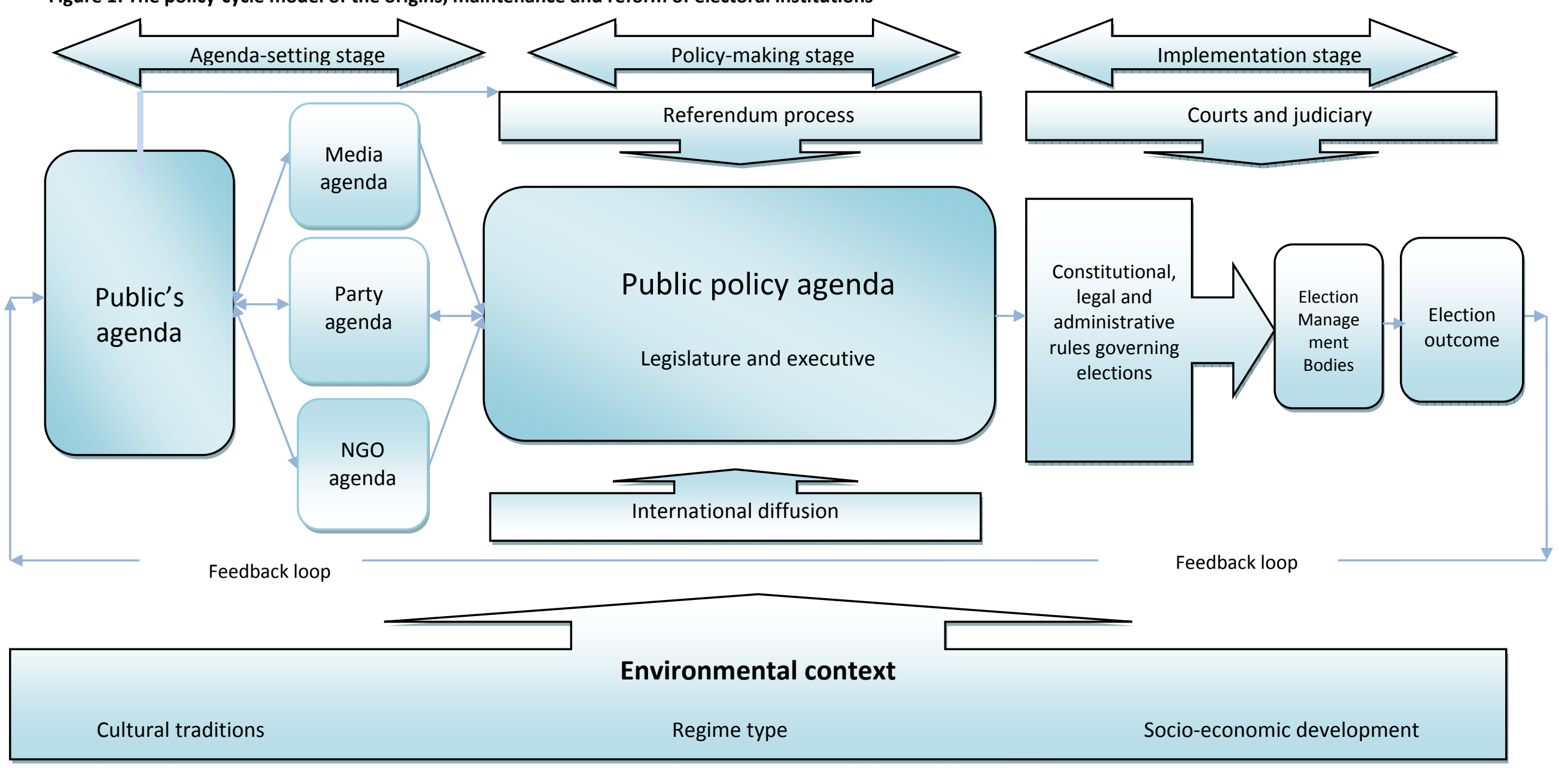


Figure 2: Democracy aspirations and the democratic record predict subsequent electoral reforms

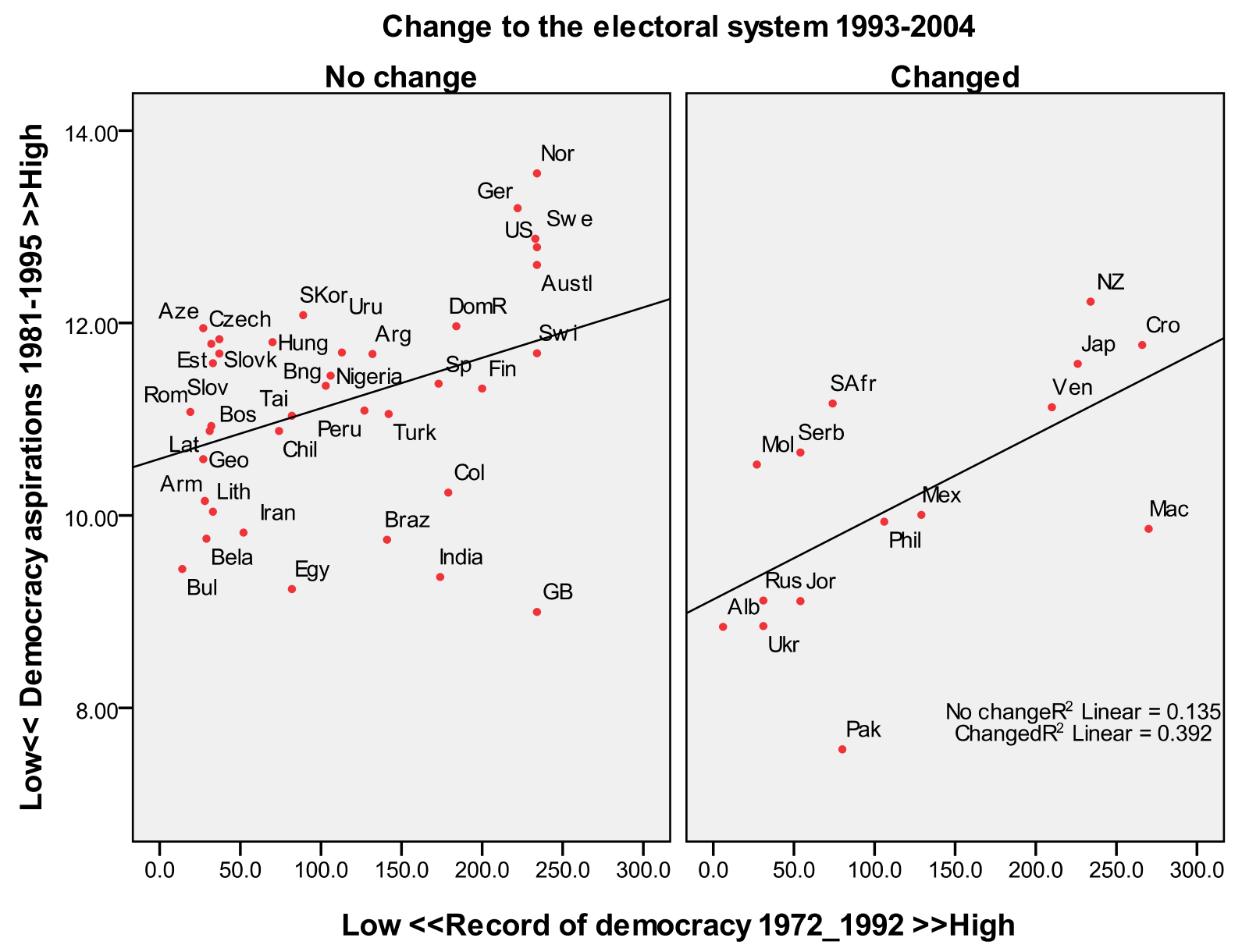

Notes: Countries are classified into groups by whether they changed their electoral system in the period from 1993-2004, as listed in Table 1A. Democracy aspirations are measured by support for democratic ideals, 1981-1995 WVS. The historic record of democracy is gauged by the summed annual index measuring civil liberties and political rights by Freedom House, 1972-1992. For details of both measures, see the technical appendix. 
Table 1: Net change matrix in the distribution of electoral systems, 1993 and 2004

\begin{tabular}{|c|c|c|c|c|c|c|c|c|c|c|c|c|}
\hline & \multicolumn{10}{|c|}{ Type of electoral system 2004} & \multirow[b]{2}{*}{$\begin{array}{l}\text { Total } \\
1993 \\
\end{array}$} \\
\hline & & FPTP & $\begin{array}{l}\text { Block } \\
\text { vote }\end{array}$ & AV & SNTV & $\begin{array}{l}\text { Two- } \\
\text { round }\end{array}$ & $\begin{array}{l}\text { Combined } \\
\text { independent }\end{array}$ & $\begin{array}{l}\text { Combined } \\
\text { dependent }\end{array}$ & List PR & STV & $\begin{array}{c}\text { No } \\
\text { elected } \\
\text { legislature }\end{array}$ & \\
\hline \multirow{20}{*}{ 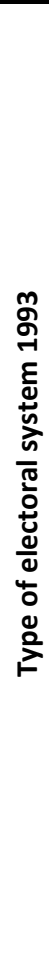 } & \multirow[t]{2}{*}{ FPTP } & 36 & 3 & 2 & 1 & 3 & 3 & 2 & 4 & & 1 & 55 \\
\hline & & $65.5 \%$ & $5.5 \%$ & $3.6 \%$ & $1.8 \%$ & $5.5 \%$ & $5.5 \%$ & $3.6 \%$ & $7.3 \%$ & & $1.8 \%$ & $100.0 \%$ \\
\hline & \multirow[t]{2}{*}{ Block vote } & & 6 & 0 & 1 & & 2 & & & & & 9 \\
\hline & & & $66.7 \%$ & $.0 \%$ & $11.1 \%$ & & $22.2 \%$ & & & & & $100.0 \%$ \\
\hline & \multirow[t]{2}{*}{ AV } & & & 2 & & & & & & & & 2 \\
\hline & & & & $100.0 \%$ & & & & & & & & $100.0 \%$ \\
\hline & \multirow[t]{2}{*}{ SNTV } & & & & 1 & & 1 & & & & & 2 \\
\hline & & & & & $50.0 \%$ & & $50.0 \%$ & & & & & $100.0 \%$ \\
\hline & \multirow[t]{2}{*}{ Two round } & & & & & 18 & 5 & & 3 & & & 26 \\
\hline & & & & & & $69.2 \%$ & $19.2 \%$ & & $11.5 \%$ & & & $100.0 \%$ \\
\hline & \multirow{2}{*}{$\begin{array}{l}\text { Combined } \\
\text { independent }\end{array}$} & & & & & & 16 & 2 & 3 & & & 22 \\
\hline & & & & & & & $72.7 \%$ & $9.1 \%$ & $13.6 \%$ & & & $100.0 \%$ \\
\hline & \multirow[t]{2}{*}{$\begin{array}{l}\text { Combined } \\
\text { dependent }\end{array}$} & & & & & & & 2 & & & & 2 \\
\hline & & & & & & & & & & & & $100.0 \%$ \\
\hline & \multirow[t]{2}{*}{ List PR } & & & & & & 2 & 3 & 55 & & 3 & 63 \\
\hline & & & & & & & $3.2 \%$ & $4.8 \%$ & $87.3 \%$ & & $4.8 \%$ & $100.0 \%$ \\
\hline & \multirow[t]{2}{*}{ STV } & & & & & & & & & 2 & & 2 \\
\hline & & & & & & & & & & $100.0 \%$ & & $100.0 \%$ \\
\hline & \multirow{2}{*}{$\begin{array}{l}\text { No elected } \\
\text { legislature }\end{array}$} & & & & & & & & & & 7 & 8 \\
\hline & & $12.5 \%$ & & & & & & & & & $87.5 \%$ & $100.0 \%$ \\
\hline \multirow{2}{*}{\multicolumn{2}{|c|}{ Total 2004}} & 37 & 9 & 4 & 3 & 21 & 29 & 9 & 65 & 2 & 12 & 191 \\
\hline & & $19.4 \%$ & $4.7 \%$ & $2.1 \%$ & $1.6 \%$ & $11.0 \%$ & $15.2 \%$ & $4.7 \%$ & $34.0 \%$ & $1.0 \%$ & $6.3 \%$ & $100.0 \%$ \\
\hline
\end{tabular}

Notes: The table lists the number (and row\% ) of independent nation states worldwide using each type of electoral system for the lower house of the national parliament in 1993 and 2004. The highlighted diagonal shows those countries which have not changed their electoral system during these years. FPTP First Past the Post; $2^{\text {nd }}$ Ballot; Block Vote; AV Alternative Vote; SNTV Single NonTransferable Vote; STV Single Transferable Vote. For the typology, see Figure 2.

Sources: Andrew Reynolds and Ben Reilly. 1997. The International IDEA Handbook of Electoral System Design. Stockholm: International Institute for Democracy and Electoral Assistance; Andrew Reynolds, Ben Reilly and Andrew Ellis. Eds. 2006. The International IDEA Handbook of Electoral System Design. Stockholm: International Institute for Democracy and Electoral Assistance ( $\left.2^{\text {nd }} \mathrm{Ed}\right)$. 
Table 2: Model predicting electoral reforms occurring from 1993-2004

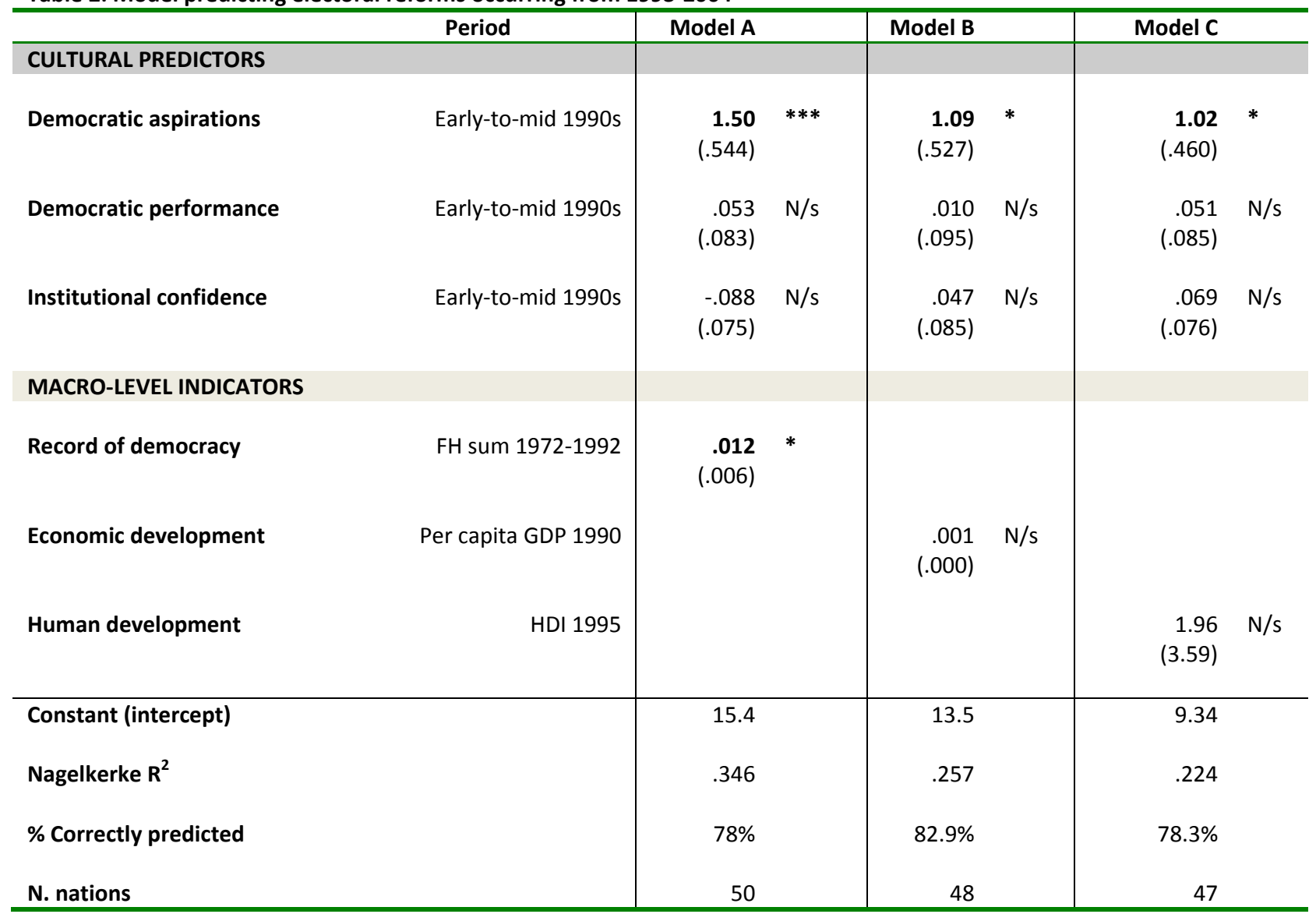

Note: Models present the results of the binary logistic regression models including the beta coefficient, (the standard error below in parenthesis), and the significance. The dependent variable is whether the country changed their electoral system from 1993-2004. The cultural and macro-level indicators were constructed from the items listed in the Technical Appendix. P.*>.05 $* *>.01 * * *>001 \mathrm{~N} / \mathrm{s}$ Not significant

Sources: See the technical appendix. 
Technical Appendix A: Concepts and Measures

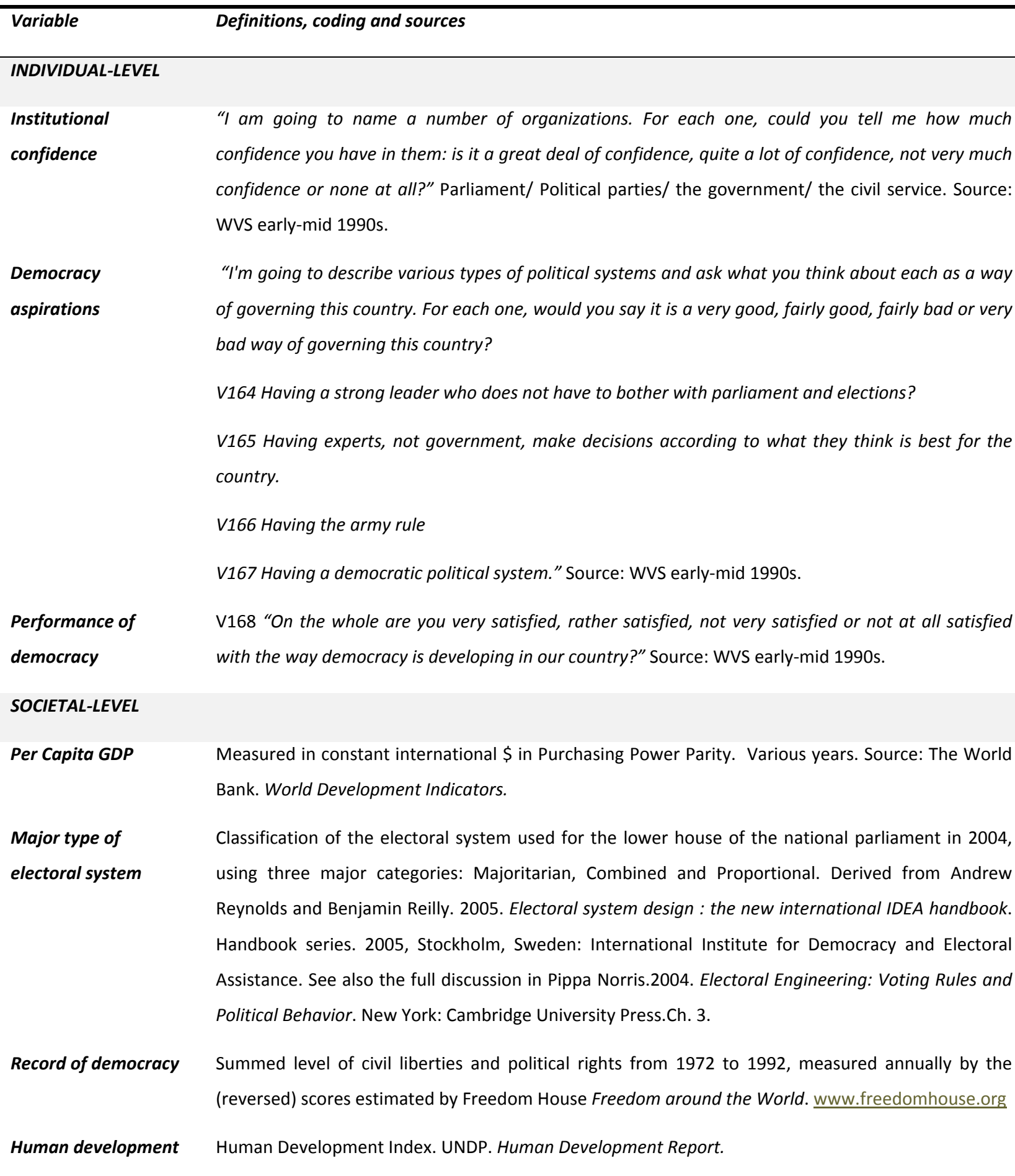

Note: International Social Survey Programme 2004: Citizenship (ISSP 2004). (ZA3950 ) Full details of the ISSP Survey codebook and questionnaire can be found at www.issp.org and the data downloaded from GESIS - Leibniz Institute for the Social Sciences. Full details of the World Values Survey codebook and questionnaire can be downloaded from www.worldvaluessurvey.org. 
Table 1A: Electoral system change, 1993-2004

\begin{tabular}{|c|c|c|c|c|}
\hline Nation & $\begin{array}{l}\text { Type of electoral system, } \\
1993\end{array}$ & $\begin{array}{l}\text { Type of electoral system, } \\
2004\end{array}$ & $\begin{array}{l}\text { Freedom House, } \\
1993\end{array}$ & $\begin{array}{l}\text { Freedom House, } \\
2004\end{array}$ \\
\hline Bolivia & List PR & Combined dependent & Free & Partly free \\
\hline Ecuador & Combined independent & List PR & Free & Partly free \\
\hline Italy & List PR & Combined dependent & Free & Free \\
\hline Japan & SNTV & Combined independent & Free & Free \\
\hline Marshall Islands & FPTP & Combined independent & Free & Free \\
\hline Monaco & Two round & Combined independent & Free & Free \\
\hline Mongolia & FPTP & Two-round & Free & Free \\
\hline New Zealand & FPTP & Combined dependent & Free & Free \\
\hline Papua New Guinea & FPTP & AV & Free & Partly free \\
\hline Tuvalu & FPTP & Block vote & Free & Free \\
\hline Albania & Combined independent & Combined dependent & Partly free & Partly free \\
\hline Croatia & Combined independent & List PR & Partly free & Free \\
\hline Fiji & FPTP & $\mathrm{AV}$ & Partly free & Partly free \\
\hline Guatemala & Combined independent & List PR & Partly free & Partly free \\
\hline Jordan & Block vote & SNTV & Partly free & Partly free \\
\hline Kazakhstan & FPTP & Combined independent & Partly free & Not free \\
\hline Lesotho & FPTP & Combined dependent & Partly free & Free \\
\hline Liberia & List PR & No elected legislature & Partly free & Partly free \\
\hline Macedonia & Two round & List PR & Partly free & Partly free \\
\hline Madagascar & List PR & Combined independent & Partly free & Partly free \\
\hline Mexico & Combined independent & Combined dependent & Partly free & Free \\
\hline Moldova, Republic Of & Two round & List PR & Partly free & Partly free \\
\hline Morocco & FPTP & List PR & Partly free & Partly free \\
\hline Pakistan & FPTP & Combined independent & Partly free & Not free \\
\hline Panama & List PR & Combined independent & Partly free & Free \\
\hline Philippines & Block vote & Combined independent & Partly free & Free \\
\hline Russian Federation & Two round & Combined independent & Partly free & Not free \\
\hline South Africa & FPTP & List PR & Partly free & Free \\
\hline Thailand & Block vote & Combined independent & Partly free & Free \\
\hline Tonga & FPTP & Block vote & Partly free & Partly free \\
\hline Ukraine & Two round & Combined independent & Partly free & Partly free \\
\hline Venezuela & List PR & Combined dependent & Partly free & Partly free \\
\hline Afghanistan & FPTP & SNTV & Not free & Not free \\
\hline Bahrain & FPTP & Two-round & Not free & Partly free \\
\hline Chad & Two round & Combined independent & Not free & Not free \\
\hline Congo, DemRep & FPTP & No elected legislature & Not free & Not free \\
\hline Eritrea & List PR & No elected legislature & Not free & Not free \\
\hline Iraq & Two round & List PR & Not free & Not free \\
\hline Korea, North & FPTP & Two-round & Not free & Not free \\
\hline Oman & No elected legislature & FPTP & Not free & Not free \\
\hline Rwanda & FPTP & List PR & Not free & Not free \\
\hline Sierra Leone & FPTP & List PR & Not free & Partly free \\
\hline Somalia & Combined independent & No elected legislature & Not free & Not free \\
\hline Syrian Arab Republic & FPTP & Block vote & Not free & Not free \\
\hline Tajikistan & Two round & Combined independent & Not free & Not free \\
\hline
\end{tabular}

Note: N. 46 out of 191 independent nation states worldwide (24.1\%). Sources: see text. 
ACE project. http://aceproject.org/.

Anderson, Christopher J. 2001. 'Winners, losers, and attitudes about government in contemporary democracies.' International Political Science Review 22: 321.

Anderson, Christopher J., 1997. 'Political institutions and satisfaction with democracy: A cross-national analysis of consensus and majoritarian systems.' American Political Science Review 91: 66-82.

Anderson, Christopher J., Andre Blais, Shaun Bowler, Todd Donovan and Ola Listhaug. 2005. Loser's Consent: Elections and Democratic Legitimacy. Oxford: Oxford University Press.

Banducci, Susan and Jeff A. Karp. 1999. 'Perceptions of fairness and support for proportional representation.' Political Behavior 21(3): 217-238.

Banducci, Susan, T. Donovan, and Jeff A. Karp. 1999. 'Proportional representation and attitudes about politics: results from New Zealand.' Electoral Studies. 18(4): 533-555.

Bartolini, Stephano and Peter Mair. 1990: Identity, Competition and Electoral Availability. Cambridge: Cambridge University Press. Pp.154-5.

Benoit, Kenneth. 2007. 'Electoral Laws as Political Consequences: Explaining the Origins and Change of Electoral Institutions.' Annual Review of Political Science 10: 363-90.

Benoit, Kenneth. 2004. 'Models of electoral system change.' Electoral Studies 23(3):363-389.

Bielasiak, Jack. 2002. 'The Institutionalization of Electoral and Party Systems in Post-Communist States.' Comparative Politics, 34(2):189-210.

Birch, Sarah. 2008. 'Electoral institutions and popular confidence in electoral processes: A cross-national analysis.' Electoral Studies. 27(2): 305-320.

Boix, Carlos. 1999. 'Setting the rules of the game: The choice of electoral systems in advanced democracies.' American Political Science Review. 93 (3): 609-624.

Booth, John A. and Mitchell A. Seligson. 2009. The Legitimacy Puzzle in Latin America. New York: Cambridge University Press. 
Boston, Jonathan, Stephen Levine, Elizabeth McLeay, and Nigel S. Roberts. 1996. New Zealand Under MMP: A New Politics? Auckland: Auckland University Press.

Bowler, Shaun, and Todd Donovan. 2007. 'Reasoning about institutional change: Winners, losers and support for electoral reforms.' British Journal of Political Science 37 (3): 455-476.

Bowler, Shaun, T. Donovan and Jeff Karp. 2006. 'Why politicians like electoral institutions: Self-interest, values, or ideology?' Journal of Politics 68(2): 434-446.

Carstairs, Andrew McLaren. 1980. A Short History of Electoral Systems in Western Europe. London: George Allen and Unwin.

Colomer, Joseph M. 2004. Handbook of Electoral System Choice. New York: Palgrave Macmillan.

Cox, Gary. 1997. Making Votes Count: Strategic Coordination in the World's Electoral Systems. Cambridge: Cambridge University Press.

Curtice, John. 2004. 'Proportional Representation in Scotland: Public Reaction and Voter Behaviour.' Representation, 40: 329-41.

Dalton, Russell J. 2004. Democratic Challenges, Democratic Choices: The Erosion of Political Support in Advanced Industrial Democracies. New York: Oxford University Press. Ch 9.

Dalton, Russell. 2004. Democratic Challenges, Democratic Choices. Oxford: Oxford University Press.

Donovan, Mark. 1995. 'The politics of electoral reform in Italy.' International Political Science Review 16(1):47-64.

Duverger, Maurice. [Orig.1954] 1964. Political Parties London: Methuen.

Dye, Thomas R. 1995. Understanding Public Policy. 8th Ed. Eaglewood Cliffs, NJ: Prentice Hall.

Easton, David. 1965. A Framework for Political Analysis. Eaglewood Cliffs, NJ: Prentice Hall.

Eckstein, Harry. 1961. A Theory of Stable Democracy. Princeton, NJ: Woodrow Wilson Center, Princeton University.

Farrell, David. 1997. Comparing Electoral Systems. London: Prentice Hall/Harvester Wheatsheaf. 
Grofman, Bernard, and Arend Lijphart, Eds. 1986. Electoral Laws and their Political Consequences. New York: Agathon Press.

Hazan, Reuven Y. 1996. 'Presidential Parliamentarism: Direct Popular Election of the Prime Minister, Israeli's New Electoral and Political System.' Electoral Studies 15(1): pp. 21-37.

Hideo, Otake. Ed. 1998. How Electoral Reform Boomeranged: Continuity in Japanese Campaigning Style. Tokyo: Japan Center for International Exchange.

Katz, Richard S. 2005. 'Why are there so many (or so few) electoral reforms?' In Michael Gallagher and Paul Mitchell. Eds. The Politics of Electoral Systems. Oxford: Oxford University Press.

Katz, Richard S. 1997. Democracy and Elections. Oxford: Oxford University Press.

Lijphart, Arend. 1994. Electoral Systems and Party Systems: A Study of Twenty-Seven Democracies, 19451990. Oxford: Oxford University Press.

Lipset, Seymour Martin. 1983. Political Man: The Social Bases of Politics (2nd ed.) (p. 64) London: Heinemann.

Lundberg, T.C.. 2007. 'Electoral system reviews in New Zealand, Britain and Canada: A critical comparison.' Government and Opposition, 42(4): 471-490.

Michael Gallagher and Paul Mitchell. Eds. 2005. The Politics of Electoral Systems. Oxford: Oxford University Press.

Nohlen, Dieter. 1996. Elections and Electoral Systems. Delhi: Macmillan.

Noiret, Serge. Ed. 1990. Political Strategies and Electoral Reforms: Origins of Voting Systems in Europe in the 19th and 20th Centuries. Baden-Baden: Nomos Verlagsgesellschaft.

Norris, Pippa. 1995. 'The Politics of Electoral Reform in Britain.' International Political Science Review 16(1): 65-78.

Norris, Pippa. 1997. 'Choosing Electoral Systems.' International Political Science Review 18(3): 297-312.

Norris, Pippa. 2001. 'The Twilight of Westminster? Electoral Reform and Its Consequences.' Political Studies. 49(5): p. 877-900. 
Norris, Pippa. 2002 'Ballots not Bullets: Electoral Systems, Ethnic Minorities and Democratization.' Chapter 8. In The Architecture of Democracy. Edited by Andrew Reynolds and Scott Mainwaring. Oxford: Oxford University Press.

Norris, Pippa. 2004. Electoral Engineering: Voting Rules and Political Behavior. New York: Cambridge University Press.

Norris, Pippa. Ed. 1999. Critical Citizens. Oxford: Oxford University Press.

Norris, Pippa. 2011. Democratic Deficits. Cambridge: Cambridge University Press.

Powell, Jr, G. Bingham. 2000. Elections as Instruments of Democracy. New Haven: Yale University Press. Rae, Douglas. 1971. The Political Consequences of Electoral Laws. [Rev. Ed.] New Haven: Yale University Press.

Rahat, Gideon. 2004. 'The study of the politics of electoral reform in the 1990s: Theoretical and methodological issues.' Comparative Politics 36(4): 461-479.

Rein Taagepera and Matthew S. Shugart. 1989. Seats and Votes: The Effects and Determinants of Electoral Systems. New Haven: Yale University Press.

Remmer, Karen L. 2008. 'The politics of institutional change: Electoral reform in Latin America 19782002.' Party Politics 14 (1):5-20.

Renwick, Alan. 2007. 'Why did national promise a referendum on electoral reform in 1990?' Political Science. 59(1): 7-22.

Reynolds, Andrew, Ben Reilly and Andrew Ellis. Eds. 2006. The International IDEA Handbook of Electoral System Design. Stockholm: International Institute for Democracy and Electoral Assistance (2nd Ed).

Reynolds, Andrew and Ben Reilly. 1997. The International IDEA Handbook of Electoral System Design. Stockholm: International Institute for Democracy and Electoral Assistance.

Sakamoto, Takayuki. 1999. 'Explaining Electoral Reform: Japan versus Italy and New Zealand.' Party Politics. 5(4):419-438. 
Scheiner, Ethan. 2008. 'Does electoral system reform work? Electoral system lessons from reforms of the 1990s.' Annual Review of Political Science 11: 161-81.

Shiratori, Rei. 1995. 'The politics of electoral reform in Japan.' International Political Science Review 16(1):79-94.

Shugart, Matthew S. and Martin P. Wattenberg. Eds. 2001. Mixed Member Electoral Systems: The Best of Both Worlds? New York: Oxford University Press.

Steven Levitsky and Lucan A. Way. 2002. 'The Rise of Competitive Authoritarianism.' Journal of Democracy 13(2): 51-65.

Tsebelis, Georges. 1990. Nested Game: Rational Choice in Comparative Politics. California: University of California Press.

Vernon Bogdanor and David Butler, Eds. 1983. Democracy and Elections. Cambridge: Cambridge University Press.

Vowles, Jack, Peter Aimer, Susan Banducci and Jeffrey Karp. 1998. Voters' Victory? New Zealand's First Election under Proportional Representation. Auckland: Auckland University Press.

Weir, Stuart. 2005. 'Waiting for change: public opinion and electoral reform. Political Quarterly. 63(2): $197-219$.

\footnotetext{
${ }^{1}$ For details, see www.worldvaluessurvey.org; www.issp.org

${ }^{2}$ Full methodological details about the World Values Surveys, including the questionnaires, sampling procedures, fieldwork procedures, principle investigators, and organization can be found at: $\underline{w w w . w o r l d v a l u e s s u r v e y . o r g}$

${ }^{3}$ These countries are ranked as equally 'free' according to the 2008 Freedom House assessments of political rights and civil liberties Freedom House. 2008. Freedom in the World. www.freedomhouse.org.
} 